\title{
Development of Traditional Arts in Traditional Javanese Marriage Ceremony in Surakarta
}

\author{
Sarwanto Sri Rochana W Sugeng Nugroho Sumarno \\ Institut Seni Indonesia (ISI) Surakarta, Indonesia
}

\begin{abstract}
Nowadays, traditional arts in Traditional Javanese marriage ceremony are increasingly replaced by other forms of art. This is partly caused by the lack of appreciation by the society to traditional arts, and also by efforts to increase efficiency in the ceremony organization by eliminating several processions usually conducted in the ceremony. This condition raises concern to traditional art performers and the Javanese culture enthusiasts. Therefore, an effort to resurrect traditional arts in Traditional Javanese marriage ceremonyhas been initiated. To give new atmosphere and feels, new dances are choreographed and new gending songs arecomposed, in which these new creations are expected to be more interesting. Moreover, dances, karawitan songs, and traditional songs are also composed to suit the contexts and atmosphere of the ongoing event. By creativity and new innovation, songs are composed for every processions of the ceremony, namely for pasrah pengantin (handover and receiving of the bride), atur pambagyo (welcoming speech), and donga (prayers). Furthermore, dances of romance theme, such as Loro Blonyo, and gendings for the newlywed couple's reception (pahargyan). The effort has been conducted in Surakarta, primarily by the civitas academica of Indonesia Institute of the Arts Surakarta. It, as a form of conservation of Javanese traditional arts of dance and karawitan, has been well-appreciated, proven by the numerous performances in many occasions of wedding ceremonies in Surakarta. The development itself has not been fully maximized, since the performers should have a fine ability in singing and dancing. Therefore, a continuous effort is necessary to socialize traditional arts in Traditional Javanese marriage ceremony.
\end{abstract}

Keywords: traditional arts, dance, tembang, marriage ceremony.

DOI: $10.7176 / \mathrm{ADS} / 76-06$

Publication date:September $30^{\text {th }} 2019$

\section{A. Introduction}

Javanese people has a tradition of conducting marriage ceremony as a sign of entering family life. They consider marriage ceremony as an important thing in human life. Each region has different marriage ceremonies, greatly influenced by socio-cultural environment prevalent in each respective society.

In Java, there are several types of marriage ceremony usually conducted by its people, such as Yogyakartastyle ceremony, Surakarta-stle ceremony, Sunda-style ceremony, Banyumas-style ceremony, Madura-style ceremony, and traditional marriage ceremony conducted by people in coastal areas, among others. Javanese people spreading across Indonesia often conduct Traditional Javanese marriage ceremony. However, the ceremony has undergone several changes, in terms of schedule of processions or parts of processions conducted.

Change in Traditional Javanese marriage ceremony cannot be avoided, since it is influenced by various socio-cultural influences in society. It is also influenced by different view of life and soul. These changes also result in the change of art form which usually becomes an integral part of the ceremony, namely karawitan (Javanese traditional music art, accompanied by traditional percussion orchestra known as gamelan) and dance. The change is also apparent on the musical instruments accompanying the ceremony, in which electric synthesizers or keyboards are used.

For young people, these changes do not constitute as a problem, while for older generation it becomes a concerning issue, since several processions of ceremony which have deep philosophical and symbolical meanings and contain important prayers for the newlywed couple or the new family are left out. With the abandonment of processions of ceremonies mentioned above, then various traditional values and wisdom become lost.

In relation to the problems aforementioned, there exist several efforts to developTraditional Javanese marriage ceremony by changing several parts of ceremony, in which several new dances and karawitan tunes are composed to conserve and develop traditional values contained in the ceremony.

\section{B. Culture and Traditional Arts in Traditional Javanese Marriage Ceremony}

Indonesia has a rich culture, and is multicultural. Indonesia has various traditional performance arts flourishing in each respective cultural environment. The variations of culture owned are united by the concept of Bhinneka Tunggal Ika (unity in diversity), which can be interpreted as various cultures united under one umbrella of Indonesian culture.

Indonesian culture experiences a rapid change as a result of globalization. The change also results into the 
shift of culture in society, which further results into loss of culture in some places. The shift and loss of culture result into change of people's lives and behavior.In relation to the problem of cultural shift, Edi Sedyawati opined that Indonesian culture nowadays tends to be less known by the general population, including the youth, since it is rivaled by pop culture. Traditional cultural inheritances are being pushed to the edge within the mass media exposure and discourse; cultural interactions between ethnicities get less facilitation and exposure. (Sedyawati,2014: 71).

Indonesia has one of the largest number of performance arts in Southeast Asia. However, this everflourishing traditional arts in Indonesia are now increasingly sidelined by the presence of various performance arts from Western or other countries considered as more interesting. The sidelining itself results in an everdecreasing number of Indonesian traditional arts varieties. It is also added by the fact that Indonesian children and youth do not know, letting alone appreciate various forms of traditional arts. They know more about modern and contemporary arts, and show disdain to learn, conserve, protect, and develop traditional arts.

Traditional arts as a part of wealth of cultural inheritance have an important role in transforming cultural elements among generations, in order to conserve identity and fighting back Western influences increasingly covering all aspects of the people's lives.

Attached to traditional arts and culture are noble values and local wisdom, which is useful as a way of life and guidelines of socializing with people. Local wisdom contains sapience with its form is determined by the respective people's cultural environment. Values of local wisdom in society life are mutual assistance, harmony, unity, togetherness, justice, tolerance, and courtesy, among others. These values are lived and applied in society life continuously. Local wisdom that is continually grown and applied in life makes the dignity and civilization of the nation increased towards perfection.

The traditional artshave noble values that should be alive and thriving in the life of society, since it can enrich the life experience, including religious experience, social experience, and aesthetic experience (beauty). They contain noble values which can build young generation's character or soul, so that the youth can have a wise character. These noble values are also often called the adiluhung values that are very important in human life.Adiluhung means "beautiful" or "high". This word is a compound of the words adi, meaning "above all", and luhung, meaning "sublime", "high", "beyond anything else", and "meaningful" (Widyastutieningrum, 2011:73). Adiluhung values deal not only with problems of estethics, but also contain philosophical, religious, educative, and ritual values which concerns about all aspects of human life. Adiluhung is associated with problems of high value, even associated with great powers in the universe in relation to worshipping the Creator or Almighty God.

These noble values are related to human values faced by humans, among them are the value of truth, loyalty, honesty, caring, struggle, sacrifice, unity, harmony, heroism, compassion, love, and justice. In traditional arts, these values are packed in such a smooth way, so it can be accepted easily and does not seem patronizing the believers. Value attached to the traditional art is an aesthetic one that involves the value of beauty in artwork. Other values always associated with the presence of traditional art are cultural, social, economic, and historical values.

\section{Traditional Arts in Traditional Javanese Marriage Ceremony}

Traditional arts as a part of culture are a crystallization of values and art thriving in society. It is by the reason that efforts of development of cultures, either tangible (able to be touched) or intangible (unable to be touched, taking form in forms which are passed along time or immaterial, in form of concepts and ideas), are conducted.

The sustainability of traditional art is very important for the people. Therefore, it is necessary to make the young generation able to love traditional arts as the noble culture of the nation that contains the important values of life, philosophy, symbols, and religion, as well as an art that has beauty and various meanings inherent, and as a part of the ritual ceremony.

The traditional arts and culture will still survive and develop well, if there is an effort to preserve them by artists, the public, and the government. Therefore, it is necessary to strive for the development or revitalization of traditional arts in traditional Javanese marriage ceremony, to enable ordinary people to love traditional arts and culture. Given the current condition, in which outside cultures, the development of information technology, and other media have a very strong influence on the younger generation, it is increasingly difficult to instill their love and appreciation for traditional arts.

Traditional Javanese marriage ceremony usually held in Surakarta Javanese society has several processions as follows: installation of blekketepe, adang sepisan, siraman, midodareni, ijab, and panggih. Each of these has their own long procession.

Installation of blekketepe is a procession involving installation of roofings for tarub, or tents to house the guests at wedding ceremony, accompanied by prayers for a successful wedding ceremony.

Adang sepisan is a tradition of first rice cooking by the holders of marriage ceremony. In doing this, the ceremony holders hope that they can serve adequate and delicious dishes to all guests.

Siraman is a tradition to bathe both the bride and the bridgegroom, which is performed by old figures who 
are choosen as to ensure that both the bride and the groom are clean and pure from all filth and bad luck. In this occasion, both the bride and the bridegroom are bathed in their own residence. Those chosen to perform Siraman must have the same gender: the bride is bathed by female figures and the bridegroom is bathed by male figures. The number of the figures is usually 7 or 11, which is adjusted to its contained and expected meanings. Siraman also has a long series of events, and one of which is dodol dawet (selling dawet/traditional sweet dessert drink).

Midodareni is a ceremony conducted in the evening before $i j a b$ (solemnization of a marriage). In this event, the bride is exposed to bridal make up and prayer so that the angels give their blessing to her and she looks beautiful and interesting when the weeding takes place. Meanwhile, the bridegroom is given advices by his prospective parents in law so that he will become a good and responsible husband to his wife, family, and society.

Ijab is an event in which the officials of the Office of Religious Affairs are invited to performthe solemnization of a marriage. Ijab a certain long sequence in which both the bride and the bridegroom promise to live in a holy marriage and to love each other forever. Ijab is witnessed by the families of both the bride and the bridegroom.

Panggih is an event where both the bride and the bridegroom meet customarily, witnessed by invited guests and friends of both sides who give blessing and who are happy for the inauguration of the marriage performed.

In the whole procession of traditional Javanese marriage ceremony, traditional arts are presented to support and accompany the event in order to make whole procession to become solemn, glorious, and authoritative. Traditional arts are present on installation of blekketepe, adang sepisan, siraman, midodareni, ijab, and panggih. Forms of traditional arts presented are macapatan, karawitan, wayangkulit (Javanese shadow puppetry) or wayang orang (Javanese drama with stories of wayang kulit), and dances. But now, some people have left the processionals and replaced irwith other art forms. Some people replaced it with electric synthesizers or, at times, with campursari or keroncong. This is supported by the offer of hotels or restaurants that offer wedding packages or even lite packages. With this wedding package, the holders only paid the expense of the cost of the package and did not arrange the wedding ceremony. In the package, no offer of traditional arts performances is present. If there is a panggih procession, it would only be accompanied by recording of gamelan orchestra playing gending Monggang, or even only by keyboards installed by styles of gending Monggang. People now also think more practically and efficiently, so they just hold the wedding and guest receptions in rented reception houses and/or at home with no preparations or special processions. This worsens the marginalization of traditional art in traditional Javanese wedding ceremonies.

\section{Development of Traditional Arts in Traditional Javanese Marriage Ceremony in Surakarta}

The present condition which sees traditional arts being increasingly erased from Traditional Javanese marriage ceremony greatly concerns traditional artists and traditional arts enthusiasts, since the growth and development of traditional arts in society lives are facilitated by the important function they have in the traditional marriage ceremony. It is often said that traditional arts "live under tarubs", or enlivened in marriage celebrations.

It is evident that traditional arts become evicted from their main place of growth, and this can make traditional arts to be extinct in people's lives. If traditional arts do not grow anymore, the noble values containing traditional wisdom would also be lost, even though traditional arts also become an expression of experiences of the soul, and national identity. Therefore, these great concerns encourage several artists to revitalize traditional arts in Traditional Javanese marriage ceremony, primarily in Surakarta.

Ten years ago, an effort to reconstruct gendings of karawitan songs by Waridi was initiated, followed by recording them for use of Traditional Javanese marriage ceremony. With the CD and cassette tapes recording, the gending instrumentals of karawitan songs for marriage ceremony can be played without having to invite a full gamelan orchestra for the occasion. However, in the same period of time, the amount of people interested in playing gending karawitan at marriage ceremonies was increasingly smaller.

Development of traditional arts, for the time being, are only conducted on processions of panggih ceremony or wedding receptions. There are several things that have been conducted in the development or revitalizationefforts, such as performance of Loro Blonyo dance in the opening ceremony, Pasrah Panampi Penganten stage, Atur Pambagya, Suguhan Tari (dance performances), and gendings. Loro Blonyo dance is a dance performed by two dancers, male and female, dressing in bridal garments, and containing uniqueness in its choreography. This dance symbolizes fertility, and embodies hope of happy and prosperous life for the newlyweds. In addition, the dance also serves as a means of entertaining the guests. The dance was choreographed by Hari Mulyatno and Sri Setyoasih, and is often performed in Surakarta, primarily to ISI's civitas academica who hold wedding ceremonies.

The presence of traditional arts in pasrah panampi penganten is evident in the macapat traditional songs used as a form of speaking by the representative of the bridesgroom's family who hands him over to the bride's family, and the representatice of the bride's family who receives the bridesgroom. Both converse by using traditional songs, accompanied by karawitan percussion orchestra and dancing. The representatives who conduct handover and receiving should be able to sing and dance well. The macapat song lyrics are also composed as per 
contextual needs. There are many particularly well-known names able to act as representatives and conduct the ceremony this way, such as Wahyu Santoso Prabowo, Wasi Bantala, S. Pamardi, Dipokusumo, Agus Prasetyo, dan Ali Marsudi. This form of pasrah manten has its own appeal to others and had begun to flourish in Solo and the surrounding areas.

Atur pambagyo (welcoming remarks) are also delivered by using traditional songs, which is at times able to be accompanied by using gamelan orchestra, as previously done by Sarwanto (Sarwanto dan Sugeng Nugroho, 2017:38-39). Pandonga or moment of prayer is also delivered in form of traditional songs. Sometimes, the prayer for newlyweds can be performed in a dance called Umbul Donga by Wahyu Santoso Prabowo. The creativity of traditional dancers and singers is much needed so that the lyrics composed in the traditional songs can touch the feelings of guests or listeners present.

Efforts to compose gendings for Traditional Javanese marriage ceremony has also been conducted, such the ones performed by Sarwanto. The gendings has been recorded to be able to be performed more easily in society. These kinds of recorded gendings has been offered in Wonogiri, Sukoharjo, Karanganyar, and Surakarta. Romance-themed dance appropriate for entertainment in marriage ceremony has been choreographed since 1970s, producing dances such as Karonsih, Enggar-Enggar, Driasmoro, Bondan Langen Sayuk, Priyambodo Mustakaweni, and Kumajaya Kumaratih. These romance-themed dances symbolize the love between man and woman, which is also hoped to be experienced by the newlyweds, as well as being a form of entertainment for the guests because of its esthetics.

Efforts of development are also conducted by KRT Hartoyo in terms of traditional bridal makeup and garments, earning positive response from general society. It is proven by many demands KRT Hartoyo received to apply bridal makeup, either in or outside Surakarta. There are many efforts that are still on process, including choreographing appropriate dance for marriage ceremonies.

\section{E. Conclusion}

Traditional arts performed in Traditional Javanese marriage ceremony contain inherent noble values and local wisdom. These can support the solemn and dignified atmosphere of the wedding as needed. The presentation, full of prayer in each occasion, is meant as a form of request to Almighty God to grant happiness and blessings to the newlywed couple. On the other hand, traditional art can still be alive and thriving in society as an effort to conserve traditional values and wisdom. Traditional arts as a part of culture which forms the national identity should still be developed in Indonesia.

\section{REFERENCES}

Afriyanto, Suhendi. Seni Gamelan dan Pendidikan Nilai. Bandung: Sunan Ambu Press, 2014.

Ahimsa Putra, Heddy Shri. "Revitalisasi Kearifan Lokal dan Jatidiri Bangsa" dalam Bacaan Budaya Bende. Vol VI No.2 Juni 2011.

Khan, Yahya. Pendidikan Karakter Berbasis Potensi Diri, Mendongkrak Kualitas Pendidikan. Yogyakarta:Pelangi Publising, 2010.

Tim Penyusun. Menuju Sujaning Budi: Pendidikan Karakter di Institut Seni Indonesia Surakarta. Surakarta: ISI Press, 2010.

Sarwanto dan Sugeng Nugroho. Panduan Pelaku Utama Upacara Resepsi Pernikahan Adat Jawa. Surakarta” ISI Press, 2017.

Sedyawati, Edi. Kebudayaan di Nusantara: Dari Keris, Tor-Tor sampai Industri Budaya. Jakarta: Komunitas Bambu,2014.

Soedarsono, Nani. "Pembudayaan Pancasila Melalui Kearifan Lokal” dalam Bacaan Budaya Bende, Vol VI No,2, Juni 2011.

Widyastutieningrum, Sri Rochana. Sejarah Tari Gambyong: Seni Rakyat Menuju Istana. Cetakan Kedua. Surakarta: ISI Press, 2011. ISI Surakarta, 2012.

Revitalisasi Tari Gaya Surakarta, Surakarta: ISI Press bekerjasama dengan Pascasarjana 